\title{
THE OCCUPATIONAL EFFECTS OF UNCONVENTIONAL (CUSTOM-MADE) HEARING PROTECTION FOR PLATINUM MINE WORKERS
}

\author{
RJ STEENKAMP \\ Business Management \\ UNISA
}

\begin{abstract}
Noise-induced hearing loss (NIHL) is on the priority list of the World Health Organisation (WHO). Hearing loss due to industrial noise exposure is the most prevalent industrial disease. Noise (above $85 \mathrm{~dB}$ ) is not only a physical hazard, but also a psychological hazard that may create or exacerbate ergonomic or mechanical hazards. Conventional hearing protection devices (HPDs) are widely applied but also misused in the mining sector. In this investigation ownership and general attitudes were measured by determining how unconventional hearing protectors (custom-made hearing protectors) (CHPDs) is experienced by the mine- workers. The results could indicate whether these protectors, which is perceived by management to be costly, sophisticated and difficult to implement on a large scale, are a viable alternative to conventional hearing protectors. The results indicated certain positive directions in terms of quality hearing conservation and confirmed that CHPDs (with its unique features) do not only protect hearing but has several other occupational benefits.
\end{abstract}

\section{OPSOMMING}

Geraasdoofheid is op die prioriteitslys van die Wêreld Gesondheidsorganisasie (WHO). Gehoorverlies wat deur industriële geraasblootstelling veroorsaak word, word as die mees prominente beroepgesondheidsiekte beskou. Geraas (bo $85 \mathrm{~dB}$ ) is nie net 'n fisiese risiko nie, maar hou ook ook psigologiese gevare in, wat ander meganiese en ergonomiese risiko's kan veroorsaak of vererger. Konvensionele geraasdempers word op grootskaal in die mynsektor gebruik, maar ook wanaangewend. In hierdie ondersoek is eienaarskap en die algemene gesindhede van gebruikers gemeet deur te bepaal hoe onkonvensionele gehoorbeskermers (doelgemaakte gehoorbeskermers) deur die mynwerkers self ervaar word. Die resultate kan as ' $n$ aanduiding dien of hierdie beskermers, wat dikwels deur bestuur as duur, gesofistikeerd en moeilik op 'n grootskaal implementeerbaar is, as 'n lewensvatbare alternatief tot konvensionele gehoorbeskermers oorweeg moet word. Die resultate toon sekere positiewe aspekte ten opsigte van gehalte gehoorkonservering en het bevestig dat doelgemaakte gehoorbeskermers (met hul unieke eienskappe) nie slegs gehoor beskerm nie, maar verskeie ander beroepsverwante voordele inhou.

Environmental management based on standards such as ISO 14 000 has to control industrial pollutants. First-level industrial noise control (noise engineering) is a high priority in the mining sector. Second- or lower-level control such as hearing conservation should be a last resort when the engineering control of noise is inadequate. Innovation in noise elimination is an enormous challenge, and success in this operations and the SHE (safety, health and environmental) management function bring much relief in second-level interventions and, in particular, hearing conservation. The following points underline the complexity of the noise control problem:

- Noise (above $\pm 85 \mathrm{~dB}$ ) is not only a physical hazard, but also a psychological hazard that may create or exacerbate ergonomic or mechanical hazards.

- In a study by Kahan and Ross (1994) the knowledge and attitudes of a group of South African mine workers towards noise-induced hearing loss and the use of HPDs (hearing protection devices) indicated that workers did not perceive noise as a health hazard.

- Ongoing research on the noticeability of environmental sounds as noise annoyance is in progress and methods to study human response to types of sound are needed since the character of the sound is a key ingredient of noticeability.

- Evaluation of human exposure to building vibration is required.

- Sound quality features significantly in rating noise from heating, ventilating, and air-conditioning systems in buildings.

- Even modern quiet technology (eg. in drilling machines) creates noise, due to physical laws when the surface is connected

Requests for copies should be addressed to:RI Steenkamp, Department of Business Management, UNISA, PO Box 392, UNISA, 0003
- Conventional ear mufflers or HPDs are widely used in mining but are causing problems in terms of wearer ownership in the mining industry and ongoing reengineering projects to eliminate hazardous noise in mines.

Noise pollution is a multifaceted problem, and the effects of noise are also multidimensional. The object should therefore not only be to eliminate long-term noise-induced hearing loss (also referred to as permanent threshold shift - PTS), but also to control noise for other occupational, medical, quality-of-worklife $(\mathrm{QWL})$ and productivity-related reasons. Occupational health addresses several groups of hazards that cause occupational diseases. Noise (and heat) can be categorised as physical hazards while annoyance due to noise also causes other injuries, absences, mistakes, stress, high blood pressure, social isolation, lack of concentration, lower productivity, annoyance due to noise and others. Noise generally has detrimental effects on speech discrimination, sleeping patterns, job achievement (accuracy), temporary hearing loss (TTS), irritation, reasoning ability and ability to solve problems (Berger, 1996:3-4). For purposes of this survey (see questionnaire) "occupational work life effects" refer to general dimensions of comfort offered by the hearing protector (eg, verbal communication while being protected from harmful noise), life at work in general, the feeling when they work, work safety, work quality and work enjoyment.

Hearing loss due to industrial noise exposure has been estimated to be the most prevalent industrial disease, and it is estimated that the world may have a hearing impaired society of up to $20 \%$. The large annual amounts paid for compensation is the symptom of a much bigger problem. Noise engineering would not be so high on the agenda if noise was under control, and noise-induced hearing loss would not be so high on the agenda if hearing conservation programmes were up to standard. This is why noise-induced hearing loss (NIHL) is prevalent and on the priority list of the World Health Organisation (WHO). 


\section{The research problem defined}

Practitioners of industrial audiology regard hearing protection as an increasingly prevalent problem world-wide (Kock, 2002). The question is asked: If hearing protection is up to standard, why is so much compensation being paid out for noise-induced hearing loss? The investigation conducted in response to this question focused on second-level noise control, namely hearing protection as a central part of hearing conservation. Hearing protectors (with reference to all conventional types) are often misused, and in general their real-world performance falls far short of the protection that properly worn and maintained hearing protectors can provide (Berger, 1996). This study refers to "properly worn and maintained hearing protectors" as unconventional hearing protectors and specifically, custommade hearing protectors. The literature (eg. publications of the Cabot Safety Corporation and the National Hearing Conservation Association of the USA) indicates the large performance gap between pre-moulded (non custom-made), laboratory tested hearing protectors such as foam earplugs and earmuffs and their practical application in mining and industry. The ownership and application of hearing protectors are compromised by several factors of which discomfort is the foremost (Berger, 1996). Comfort has several dimensions and should be viewed in terms of physical comfort as determined by physical fit, ventilation, sound control (level of attenuation or noise reduction rate), speech discrimination, localisation and level of isolation (Kock, 2002). The underlying causes of the problem are:

- Whereas ear canals are not round, the design of conventional hearing protectors are based on the assumption that they are round. The main feature of custom-made hearing protectors is comfort, and they are designed so that mine workers will not have to adjust them for a snug fit (Kock, 2002).

- PPE (personal protective equipment, such as hearing protection devices) implies user choice. Berger (1996) recommends that comfortable hearing protectors must be selected and employees must be encouraged to make the final decision as to which they will use. Durability (eg. the type of material) and other quality dimensions (appearance, packaging, maintainability, imbedded personal ID or name, and colour choice) play an important role in truly personalised (custom-made) hearing protectors.

- Berger and Royster (1996:5) states that communication needs and hearing ability are neglected or overlooked in favour of choosing the hearing protector with the highest NRR (noise reduction rate). Noise control implies not only attenuation (noise reduction) but also noise filtering that allows the penetration of certain sounds, such as warning signals and verbal communication, but blocks the passage of harmful noise.

- Custom-fitted hearing protectors are fitted and seal-tested on site (outside the laboratory) for quality assurance purposes and improved NRR performance (Schophaus, 2001). Hearing protection was such a big problem in the past, that it is worth the effort to spend time with each mine worker and make sure his hearing protector is specially made for him and calibrated for his environment.

- The use of custom-fitted hearing protectors increases among workers with identified noise-induced hearing loss. The report "use and non-use of custom-molded and conventional hearing protectors among workers occupationally exposed to hazardous noise" by Bennet (1999:2) from the United States Air Force confirms this interesting trend. Certain platinum mine managers is of belief that a true prevention drive will have the same effect and will lead to the increased use of custom-made hearing protectors among workers without identified NIHL.

This report/article focuses on the general value and occupational effects of custom-made hearing protectors, largely regarded as unconventional hearing protection devices, that is perceived to be costly and not suited for large scale application for mine workers. Legislation and specifically the SA Mine Health and Safety Act (MHS) demands the provision of hearing protection, but also elaborates on personal protective equipment (PPEs) that promotes ergonomics (an important QWL dimension) (section 21(1) c of the MHS). This is an additional reason why quality hearing protection is sought.

The quality dimensions of the custom-made hearing protection device are very different from conventional hearing protectors. Custom-made hearing protectors are medically made by taking moulds of each worker's ear and fitted (and seal tested) again after manufacture and assembly. It has several unique features such as a filter mechanism (calibrated to attenuate noise for the specific noise area to eliminate overprotection and allow speech discrimination), cost-effectiveness and amongst others, is made of hard durable material. Top management of mine houses is particularly interested in cost-effectiveness with reference to direct and indirect costs. Compensation payments for NIHL (which amount millions per annum) can be eliminated and the direct cost benefit is also a factor. If Anglo Platinum for instance, invested R3 per head per day on conventional hearing protectors, it could amount to $\pm \mathrm{R} 800$ per annum for "ineffective" protectors. The average cost for custom-made hearing protectors is $\mathrm{R} 400$ per set that can last for at least five years. This indicates a possible estimated saving of $90 \%$ if the unconventional route is followed. This simple estimate does not include other possible indirect savings in terms of productivity and the prevention of NIHL. The following report is based on a survey among workers randomly selected at the second largest platinum mine in Rustenburg, South Africa.

\section{AIMS OF THIS ARTICLE}

\section{Main aim}

The aim of this article is to find solutions to mining's environmental risk in the specific form of management's hearing protection and hearing conservation problem (Steenkamp, 1999). The primary focus was to determine the occupational effects (related to health, safety and productivity) of quality hearing protection. This was done by determining how unconventional hearing protectors (custom-made hearing protection) is experienced and perceived by mine workers. The outcome of this survey was intended to be a significant indicator for management, who perceives custom-made hearing protectors to be costly and difficult to implement on a large scale, as a viable alternative to conventional hearing protectors (well known ear muffs and different types of pre-molded ear plugs). The result will therefore indicate direction towards hearing protection practices as a vital part of hearing conservation as lower level noise control. The main aim is therefore to find solution(s) to this research problem (and mining's practical problem) as defined in the previous section.

\section{Sub-aim}

The sub-aim was to obtain the wearer's testimony whether and in what terms he experiences the custom-made hearing protector to effect his work. Quality hearing conservation can have values beyond the elimination of noise-induced hearing loss in that it can serve to promote general health, improve safe working practices and affect quality and productivity positively. Medical investigations (eg, audiometric testing) would be the only valid measure to determine the level of hearing ability (hearing health status) of each worker as compared to a base-line measurement. This was not the purpose of the survey, neither to measure if they were indeed working safer, making less mistakes and improved their occupational life or not. In a report on 588692 industrial audiometric tests, Rink (1996) confirmed these and other benefits of a quality hearing conservation programme. The secondary objective (sub-aim) was thus to determine the degree of improvement (if any) by analysing the different views on each variable (the degree of dissatisfaction or satisfaction) between 
the users who have both used conventional and unconventional hearing protectors. The effects (relationship) of the custommade hearing protector (and its dimensions) on the mineworkers' occupational work life (and its dimensions) were analyzed to determine which dimensions relate to which work life effect.

\section{RESEARCH METHODOLOGY}

The survey demanded components of a qualitative personal research design. Each mine worker $(n=286)$ had to be consulted, observed and interviewed due to their low education levels and high validity demanded by management. Other factors, such as trained translators (eg, Phd qualified in African languages), operations down time and the lengthy survey procedure complicated the research design.

Two research teams did a personal survey (with advantages of qualitative observation and quality control) with the support and cooperation of the Mine's environmental and occupational hygiene team. Each of the research teams consisted of a scheduler (who paraded the workers), an interviewer and an interpreter. Structured questions (see Table 1) as approved by trade-unions and management had to be very simple due to the nature of the respondents and the mentioned circumstances of the mineworkers. A four-point scale $(0=$ very negative and $3=$ very positive) was used to eliminate the middle order effect.

Six items of the questionnaire focused on the unconventional hearing protection device (custom-made hearing protection device) and its features, and six items were focused on the resulting occupational work-life effects of the unconventional hearing protection device. Amongst others, all 12 items would measure ownership and the degree of satisfaction of the custommade hearing protection device.

The survey was conducted by first subjecting 1500 workers with (and who wore) conventional hearing protection devices for a period of a year (or longer), and by then subjecting the same workers - who were then fitted with (and wore) a custom-made hearing protection device for a year or more. A random sample of $20 \%$ (those male miners working in the same noise levels of $110 \mathrm{~dB})$ were identified from three mine shafts and paraded (scheduled) for the survey. This sample comprised 286 mine workers who participated in this survey over a period of four weeks. The workers are paraded regularly and understand the importance of medical related check-ups and the way the interpreters handled the survey assured voluntary participation.

\section{Limitations}

Besides the obvious practical limitations mentioned, the possible influencing factor on the perception of the subjects due to the Hawthorne effect needs mentioning (Flippo, 1980:482). Factors such as the special attention allocated, the involvement in decision making (workers have a colour choice and their name is imbedded into the custom-made hearing protector) and the new change in the environment (new type of hearing protector) could have an inaccurate (overly positive) effect on the results. But it must be noted that the Hawthorne effect may especially be in operation during short-term studies which was not the case.

\section{RESULTS}

\section{General observation}

The research team and mine supervisors made, amongst other positive observations, one specific important observation. It was evident that workers were ready to be interviewed and could easily be communicated with after a noisy (average 110dB) mine shift. Previously with conventional hearing protection, workers suffered TTS (temporary threshold shift which is a temporary deafness) due to noise above 85 decibels. This made and would make communication or interviews almost impossible.

In general the observers could easily identify problems such as poor fitment, a need for custom-made hearing protection (abbreviation: CHPD) training or poor maintained units. But, in general it was clearly observed (through observation, interviews and the questionnaire survey) that workers valued the new hearing protectors highly. Ownership of the CHPD is high and feedback such as "it changed my life" and "everyone must be fitted", were regarded as significant. The PPE topic is not usually very exited, but during this survey workers enjoyed the discussions and cooperation was spontaneous.

\section{Validity of the questionnaire: factorial structure}

Factor analysis is a statistical technique that is particularly well suited for the investigation of the underlying structure of a questionnaire (Kerlinger, 1984:569). Factor analysis is especially useful when the purpose is to uncover dimensions in a questionnaire. Items that refer to or share the same dimension should correlate highly with one another, and factor analysis uses this correlation to uncover factors or dimensions.

The items/questions of the scale in the survey (see figure 2 for the $0,1,2,3$ scale used with each item) were subjected to a factor analysis. The question is: "Do all the items belong to a single factor or dimension, or can other 'dimensions' be identified?" For this purpose, the eigenvalues associated with underlying factors are plotted against the factors' numbers, and Cattell's socalled scree test (Stevens \& James,1992:388) was performed, which involved studying the slope of the plotted eigenvalues. The eigenvalue of a factor indicates the amount of variance that the factor explains of the data. The larger the eigenvalue of a factor relative to the size of the eigenvalues of the other factors, the more variance the factor explains.

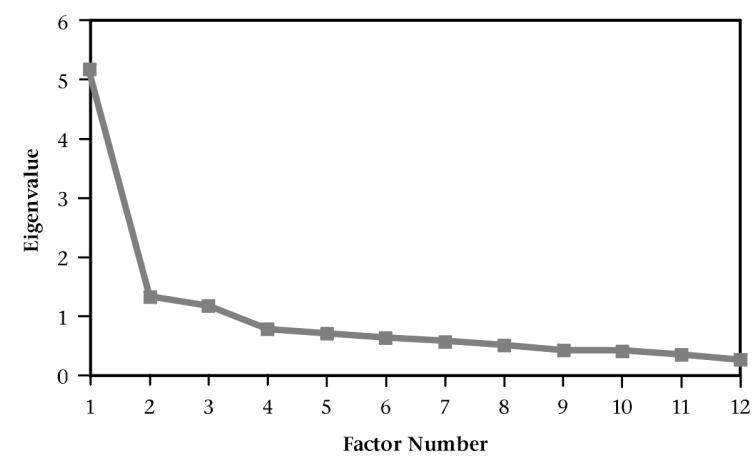

Figure 1:Eigenvalues for the Hearing Protection Survey

From the Plot of the Eigenvalues in Figure 1 above, it would appear that the extraction of three factors are indicated since three factors have eigenvalues larger than 1,0 and the "scree" (line plot levels off) appears to begin at factor 4 .

A principal axis factor analysis was subsequently performed on the inter-correlation matrix of the 12 items and three factors extracted. The solution was obliquely rotated according to the Promax criterion (Mulaik, 1975) using SAS for Windows release 8.02 (SAS, 1999-2001). The rotated factor pattern solution is reported in Table 1 below.

The significant factor loadings have been highlighted in Table 1 on the next page. It is clear that factor III comes about because of item 3 and item 4 being closely associated. As only two items loaded on this factor, one would not treat this factor III as a separate dimension. A two-factor solution (which is not reported here) was also obtained but this factor III still featured while all other items loaded on the remaining factor. It is seems as if the primary difference between factors I and II is that factor II might 
refer to work-related (how they work in terms of general safety, productivity and quality) issues, whereas factor I refers to more personal, sensuous and CHPD ownership type issues. As item 1 ("It is better than previous one") is of particular interest, it may be noted that it loads highly together with items such as "it is comfortable", "improve life at work", etc. The determinants of item 1 were also investigated by means of an stepwise regression analysis and this is reported below.

TABLE 1

Rotated Factor Pattern (Standardized Regression Coefficients) (Rotation Method: Promax (Power = 3)

\begin{tabular}{lccc}
\hline \multirow{2}{*}{ Items } & \multicolumn{3}{c}{ Factors } \\
\cline { 2 - 4 } & I & II & III \\
\hline ITEM2 It is comfortable & 0.91 & -0.21 & 0.07 \\
ITEM1 It is better than previous one & $\mathbf{0 . 8 0}$ & -0.06 & 0.08 \\
ITEM7 improve life at work & $\mathbf{0 . 6 6}$ & 0.27 & -0.05 \\
ITEM6 Likes the color & $\mathbf{0 . 5 8}$ & 0.08 & 0.00 \\
ITEM8 Feel better when you work & $\mathbf{0 . 5 8}$ & 0.36 & -0.11 \\
ITEM12 Enjoy work more & $\mathbf{0 . 4 7}$ & 0.22 & -0.06 \\
ITEM5 It protects hearing & $\mathbf{0 . 3 7}$ & 0.31 & 0.21 \\
ITEM11 Work better with less faults & -0.08 & $\mathbf{0 . 8 5}$ & 0.09 \\
ITEM9 Produce more on the job & 0.07 & 0.84 & -0.14 \\
ITEM10 Work safer & 0.06 & 0.66 & 0.23 \\
ITEM4 Hears other sounds better & -0.05 & 0.08 & $\mathbf{0 . 9 0}$ \\
ITEM3 Communication on the job & 0.07 & -0.04 & $\mathbf{0 . 8 6}$ \\
\hline
\end{tabular}

The unconventional hearing protection device is perceived to be better than conventional hearing protection devices The general attitudes of the workers towards the CHPD and how well it works for them is summarised by Tables 2 and 3 as well as Figures 2 and 3 below. The average scores of the responses on a scale that ranges from 0 (very bad or disagree) to 3 (very good/strongly agree), indicates the worker's general attitude towards each question asked. The mean scale score for the question, "Is the new custom-made hearing protection device better than the previous one?" in Table 3 and Figure 2 below indicates that workers do actually feel strongly that the unconventional hearing protection device is better than the conventional one.

TABLE 2

MEANS AND STANDARD DEVIATIONS OF THE QUESTIONS PERTAINING TO THE CUSTOM-MADE HEARING PROTECTION DEVICE (CHPD)

\begin{tabular}{lccccc}
\hline & N & Minimum & Maximum & Mean & $\begin{array}{c}\text { Std } \\
\text { deviation }\end{array}$ \\
\hline $\begin{array}{l}\text { It is better than } \\
\text { previous one }\end{array}$ & 285 & 0 & 3 & 2.49 & .695 \\
It is comfortable & 286 & 0 & 3 & 2.35 & 723 \\
Good communication & 286 & 0 & 3 & 2.13 & .684 \\
on the job & & & & & \\
Hears other sounds better & 286 & 0 & 3 & 2.18 & .623 \\
It protects hearing & 281 & 0 & 3 & 2.36 & .593 \\
Likes the colour & 285 & 0 & 3 & 2.65 & .548 \\
Valid N (listwise) & 279 & & & & \\
\hline
\end{tabular}

The mean score for the total questionnaire was 2.30 with a standard deviation of 0.400 . These means for each separate question are illustrated graphically in Figures 2 and 3 below.

It is clear from Tables 2 and 3, and from Figures 2 and 3, that a mean score above 2 ("good") was obtained for all the questions. The items that scored particularly high were, the CHPD is better than the previous HPD; the CHPD is comfortable; the CHPD protects the wearer's hearing; and the colour of a CHPD is important (aesthetic appeal). Other items that received a relatively lower score, although still good, were the following:

- The CHPD enables better communication on the job.

- The CHPD helps the subject/wearer to hear other sounds better

- The CHPD helps the subject to increase his/her productivity on the job.

TABLE 3

MEANS AND STANDARD DEVIATION FOR THE QUESTIONS PERTAINING TO THE RESULTING OCCUPATIONAL WORK LIFE EFFECTS OF THE CUSTOM-MADE HEARING PROTECTION DEVICE (CHPD)

\begin{tabular}{lccccc}
\hline & N & Minimum & Maximum & Mean & $\begin{array}{c}\text { Std } \\
\text { deviation }\end{array}$ \\
\hline Improve life at work & 286 & 0 & 3 & 2.30 & .581 \\
$\begin{array}{l}\text { Feel better when } \\
\text { you work }\end{array}$ & 286 & 0 & 3 & 2.27 & .583 \\
Produce more on the job & 284 & 0 & 3 & 2.15 & .506 \\
Work safer & 285 & 0 & 3 & 2.27 & .499 \\
Work better with & 286 & 0 & 3 & 2.25 & .536 \\
less faults & & & & & \\
Enjoy work more & 284 & 0 & 3 & 2.36 & .599 \\
Valid N (listwise) & 281 & & & & \\
\hline
\end{tabular}

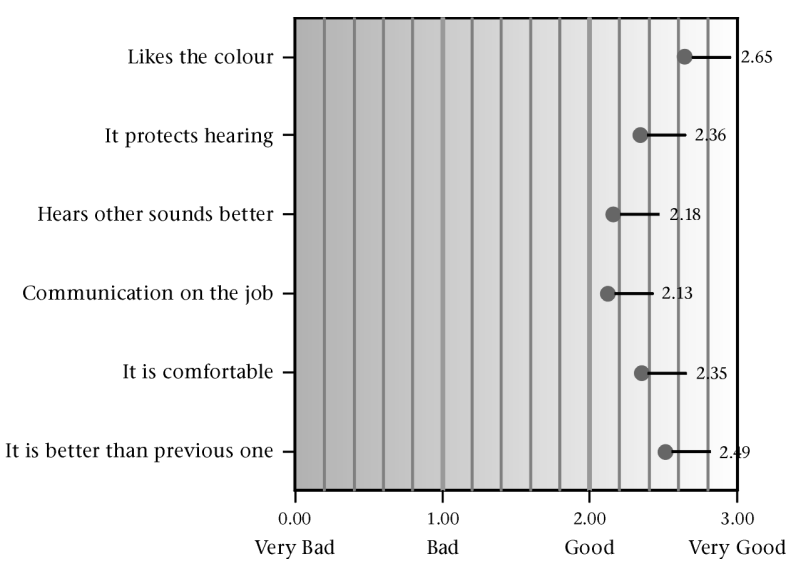

Figure 2: Means of the items pertaining to what respondents think of the custom-made hearing protection device (CHPD) and its features

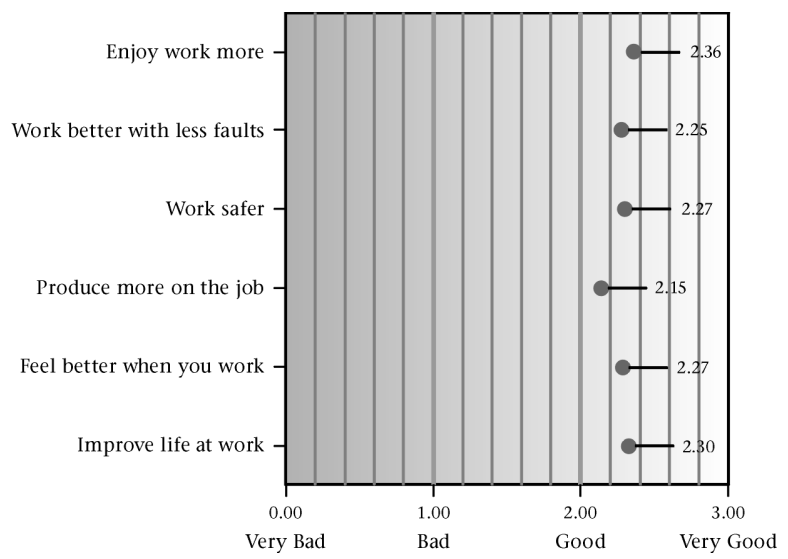

Figure 3: Means of the items pertaining to the resulting work life effects of the custom-made hearing protection device

Regression analysis to identify important CHPD dimensions The first question (item 1) was the most important indicator since it divided respondents between their attitudes towards conventional and unconventional hearing protectors. It can be concluded that the respondents feel strongly that the CHPD is better than the previous HPD (see Table 1). A stepwise regression 
was performed to determine which factors contributed most to the CHPD being seen as better than its predecessor. See Table 4 for the regression-analysis results with the following dependent variable: "Is the new HPD better than the previous HPD?"

\section{TABLE 4}

REGRESSION ANALYSIS: DEPENDENT VARIABLE IS THE ITEM "IT IS BETTER THAN PREVIOUS ONE"

\begin{tabular}{lcrc}
\hline Model & $\begin{array}{c}\text { Standardised } \\
\text { Coefficients } \\
\text { Beta }\end{array}$ & $\mathrm{T}$ & Sig. \\
\hline It is comfortable & .530 & 10.868 & .000 \\
Work safer & .142 & 2.861 & .005 \\
Likes the colour & .109 & 2.150 & .032 \\
It protects hearing & .110 & 2.095 & .037 \\
\hline
\end{tabular}

$\mathrm{R}=.708 \quad \mathrm{R}^{2}=.0 .502$

The results of regression analysis indicated that the following four factors mainly contribute (about $50 \%$ of the variance of the dependent variable) to the CHPD being regarded as better than the previous hearing protection device:

- The CHPD is comfortable.

- The CHPD protects the subject's hearing.

- The colour of the CHPD is aesthetically pleasing.

- The CHPD helps the subject to work safer.

Positive correlations between the collective view (perception) of the unconventional hearing protection device and the other questions

A correlation analysis found that there are strong positive correlations between all the questions of the survey (at the 0.005 level). This means that each question has a direct positive relationship with the other questions; as one question tends to be answered positively (high) the other questions are also answered positively (high). The complete correlation table for all the questions can be seen in Table 6 , but for the purposes of this discussion only the correlations between question 1 (Is the new HPD better than the previous one?) and the other questions are given in Table 5 below.

\section{TABLE 5}

Correlations between Question 1 (ITEM 1) AND THE OTHER QUESTIONS

\begin{tabular}{|c|c|c|}
\hline $\begin{array}{l}\text { Unexpected End } \\
\text { of Formula }\end{array}$ & Other questions & $\begin{array}{l}\text { It is better than } \\
\text { the previous HPD } \\
\text { (Question 1) }\end{array}$ \\
\hline It is comfortable & $\begin{array}{l}\text { Pearson Correlation } \\
\text { Sig. (2-tailed) }\end{array}$ & $\begin{array}{c}.680(* *) \\
.000\end{array}$ \\
\hline Communication on the job & $\begin{array}{l}\text { Pearson Correlation } \\
\text { Sig. (2-tailed) }\end{array}$ & $\begin{array}{c}.341(* *) \\
.000\end{array}$ \\
\hline Hears other sounds better & $\begin{array}{l}\text { Pearson Correlation } \\
\text { Sig. (2-tailed) }\end{array}$ & $\begin{array}{c}.312(* *) \\
.000\end{array}$ \\
\hline It protects hearing & $\begin{array}{l}\text { Pearson Correlation } \\
\text { Sig. (2-tailed) }\end{array}$ & $\begin{array}{c}.433(* *) \\
.000\end{array}$ \\
\hline Likes the colour & $\begin{array}{l}\text { Pearson Correlation } \\
\text { Sig. (2-tailed) }\end{array}$ & $\begin{array}{c}.395\left(^{* *}\right) \\
.000\end{array}$ \\
\hline Improve life at work & $\begin{array}{l}\text { Pearson Correlation } \\
\text { Sig. (2-tailed) }\end{array}$ & $\begin{array}{c}.506(* *) \\
.000\end{array}$ \\
\hline Feel better when you work & $\begin{array}{l}\text { Pearson Correlation } \\
\text { Sig. (2-tailed) }\end{array}$ & $\begin{array}{c}.469\left(^{* *}\right) \\
.000\end{array}$ \\
\hline Produce more on the job & $\begin{array}{l}\text { Pearson Correlation } \\
\text { Sig. (2-tailed) }\end{array}$ & $\begin{array}{c}.341(* *) \\
.000\end{array}$ \\
\hline Work safer & $\begin{array}{l}\text { Pearson Correlation } \\
\text { Sig. (2-tailed) }\end{array}$ & $\begin{array}{c}.428(* *) \\
.000\end{array}$ \\
\hline Work better with less faults & $\begin{array}{l}\text { Pearson Correlation } \\
\text { Sig. (2-tailed) }\end{array}$ & $\begin{array}{c}.339(* *) \\
.000\end{array}$ \\
\hline Enjoy work more & $\begin{array}{l}\text { Pearson Correlation } \\
\text { Sig. (2-tailed) }\end{array}$ & $\begin{array}{c}.333\left({ }^{* *}\right) \\
.000\end{array}$ \\
\hline
\end{tabular}

** Correlation is significant at the 0.01 level (2-tailed).
The question "Is the CHPD better than the previous HPD?" correlates positively with all the other questions, but especially well with the question on "comfort", "improvement of life at work" and "feel better when you work". The latter two were not indicated by the regression analysis results but should be considered as an important determinant of whether workers consider the CHPD better than the previous HPD or not.

The correlations between the different dimensions offered by the CHPD and the resulting work life effects

The Pearson Product moment correlation coefficient was computed between the 12 items and these correlations are reported in table 6 . To reduce the data, some of the high intercorrelations are pointed out in the factor solution matrices.

\section{CONCLUSIONS AND RECOMMENDATIONS}

Conclusions in terms of the research aim

The conclusions and recommendations are made with reference to the aim and sub-aim (section 2). The research team's observation is very positive and the overall conclusion is in favour of the unconventional CHPD. It was observed that the workers actually wear the CHPD, which is a very significant improvement. In terms of the main aim of the investigation, the results must be seen as indicative of a possible new norm in hearing protection. CHPDs is experienced and perceived to be a major improvement in terms of the mentioned occupational effects. The results of the survey can also be seen as a hypothesis that a CHPDs is indeed a better hearing protector in terms of worker's medical and occupational hygiene hearing ability status (hearing health and in what measures it eliminates NIHL). To test this hypotheses, hard medical facts such as audiometric measurements as compared to a base-line measurement needs to be studied.

In terms of the sub-aim, this survey very positively indicates that the new CHPD improves work in terms of quality, safety and productivity. It seems as if quality hearing protection has values (occupational work life effects) beyond hearing protection (not for hearing only). Another hypotheses is thus generated, namely that CHPDs improves several dimensions of quality, safety and productivity.

Conclusions in terms of the qualitative observations

Items observed can be summarised into three groups: the affective (feelings about the CHPD), their work related responses and the physical condition (and way the CHPD was applied) of the CHPD. It was clear which workers wore them correctly and the correlation between these three groups were positive if workers wore/use the CHPD correctly (and the opposite if not). With reference to the results in terms of the general observation, it is reported that the teams had a surprisingly positive response in terms of the cooperation of role players, their enthusiasm to share their experiences and indicate their feelings about the items observed. It was clear that hearing protection for platinum mineworkers is important for them and it was also observed that this was not previously the case. Those workers that were fitted correctly (without any fitment problem such as the incorrect application of the CHPD) were all very positive in terms of the 12 items (occupational effects). Some even reported that the CHPD changed their lives (not only hearing protection) positively. Comments such as "save the ears of your life" and "go from HPD to PHD" were interesting.

Conclusions in terms of the statistical analysis

The results as indicated (summarized in table 1) clearly shows the unconventional hearing protection device (CHPD) is regarded as better than the previous conventional type (second highest score of 2.49). The results also indicate comfort and durable appearance (looks and color) is critical while hearing is protected. Workers 
TABLE 6

Correlations Between ALL THE QUESTIONS IN THE HEARING PROTECTION SURVEY

\begin{tabular}{|c|c|c|c|c|c|c|c|c|c|c|c|c|c|}
\hline & & $\begin{array}{c}\text { It is } \\
\text { better } \\
\text { than } \\
\text { previous } \\
\text { one }\end{array}$ & $\begin{array}{c}\text { It is } \\
\text { comfortable }\end{array}$ & $\begin{array}{c}\text { Communication } \\
\text { on the job }\end{array}$ & $\begin{array}{c}\text { Hears } \\
\text { other } \\
\text { sounds } \\
\text { better }\end{array}$ & $\begin{array}{c}\text { It } \\
\text { protects } \\
\text { hearing }\end{array}$ & $\begin{array}{l}\text { Likes the } \\
\text { color }\end{array}$ & $\begin{array}{c}\text { Improve } \\
\text { life } \\
\text { at work }\end{array}$ & $\begin{array}{c}\text { Feel } \\
\text { better } \\
\text { when you } \\
\text { work }\end{array}$ & $\begin{array}{c}\text { Produce } \\
\text { more } \\
\text { on the } \\
\text { job }\end{array}$ & $\begin{array}{l}\text { Work } \\
\text { safer }\end{array}$ & $\begin{array}{c}\text { Work } \\
\text { better } \\
\text { with less }\end{array}$ & $\begin{array}{l}\text { Enjoy } \\
\text { work } \\
\text { more } \\
\text { faults }\end{array}$ \\
\hline \multirow[t]{3}{*}{$\begin{array}{l}\text { It is better than } \\
\text { previous one }\end{array}$} & $\begin{array}{l}\text { Pearson } \\
\text { Correlation }\end{array}$ & 1 & $.680(* *)$ & $.341(* *)$ & $.312\left({ }^{* *}\right)$ & $.433\left({ }^{* *}\right)$ & $.395(* *)$ & $.506\left(^{* *}\right)$ & $.469\left({ }^{* *}\right)$ & $.341\left(^{* *}\right)$ & $.428\left(^{* *}\right)$ & $.339\left(^{* *}\right)$ & $.333\left({ }^{* *}\right)$ \\
\hline & Sig. (2-tailed) & & .000 & .000 & .000 & .000 & .000 & .000 & .000 & .000 & .000 & .000 & .000 \\
\hline & $\mathrm{N}^{\circ}$ & 285 & 285 & 285 & 285 & 280 & 284 & 285 & 285 & 283 & 284 & 285 & 283 \\
\hline \multirow{3}{*}{$\begin{array}{l}\text { It is } \\
\text { comfortable }\end{array}$} & Pearson & $.680\left(^{* *}\right)$ & 1 & $.322\left({ }^{* *}\right)$ & $.302(* *)$ & $.385(* *)$ & $.368\left({ }^{* *}\right)$ & $.542\left({ }^{* *}\right)$ & $.481\left({ }^{* *}\right)$ & $.268\left({ }^{* *}\right)$ & $.370\left(^{* *}\right)$ & $.225(* *)$ & $.317(* *)$ \\
\hline & Correlation & & & & & & & & & & & & \\
\hline & $\mathrm{N}$ & 285 & $286^{\circ}$ & 286 & 286 & 281 & .000 & 286 & 286 & .000 & $\begin{array}{r}.000 \\
285\end{array}$ & $\begin{array}{r}.000 \\
286\end{array}$ & 284 \\
\hline \multirow[t]{3}{*}{$\begin{array}{l}\text { Communication } \\
\text { on the job }\end{array}$} & $\begin{array}{l}\text { Pearson } \\
\text { Correlation }\end{array}$ & $.341\left(^{* *}\right)$ & $.322\left({ }^{* *}\right)$ & 1 & $.654(* *)$ & $.303\left(^{* *}\right)$ & $.251\left({ }^{* *}\right)$ & $.337\left(^{* *}\right)$ & $.301\left({ }^{* *}\right)$ & $.178(* *)$ & $.366\left({ }^{* *}\right)$ & $.286\left({ }^{* *}\right)$ & $.247\left(^{* *}\right)$ \\
\hline & Sig. (2-tailed) & .000 & .000 & . & .000 & .000 & .000 & .000 & .000 & .003 & .000 & .000 & .000 \\
\hline & $\mathrm{N}$ & 285 & 286 & 286 & 286 & 281 & 285 & 286 & 286 & 284 & 285 & 286 & 284 \\
\hline \multirow{3}{*}{$\begin{array}{l}\text { Hears other } \\
\text { sounds better }\end{array}$} & $\begin{array}{l}\text { Pearson } \\
\text { Correlation }\end{array}$ & $.312(* *)$ & $.302(* *)$ & $.654\left({ }^{* *}\right)$ & 1 & $.449(* *)$ & $.211\left({ }^{* *}\right)$ & $.285\left(^{* *}\right)$ & $.250(* *)$ & $.236\left({ }^{* *}\right)$ & $.409\left({ }^{* *}\right)$ & $.314\left({ }^{* *}\right)$ & $.216(* *)$ \\
\hline & Sig. (2-tailed) & .000 & .000 & .000 & & .000 & .000 & .000 & .000 & .000 & .000 & .000 & .000 \\
\hline & $\mathrm{N}$ & 285 & 286 & 286 & 286 & 281 & 285 & 286 & 286 & 284 & 285 & 286 & 284 \\
\hline \multirow{4}{*}{$\begin{array}{l}\text { It protects } \\
\text { hearing }\end{array}$} & Pearson & $.433\left(^{* *}\right)$ & $.385\left(^{* *}\right)$ & $.303\left({ }^{* *}\right)$ & $\left..449{ }^{* *}\right)$ & 1 & $.482\left(^{* *}\right)$ & $.478\left({ }^{* *}\right)$ & $\left..480{ }^{* *}\right)$ & $.409\left({ }^{* *}\right)$ & $.440\left(^{* *}\right)$ & $.417\left(^{* *}\right)$ & $.290(* *)$ \\
\hline & Correlation & & & & & & & & & & & & \\
\hline & Sig. (2-tailed) & .000 & .000 & .000 & .000 & & .000 & .000 & .000 & .000 & .000 & .000 & .000 \\
\hline & $\mathrm{N}$ & 280 & 281 & 281 & 281 & 281 & 280 & 281 & 281 & 279 & 280 & 281 & 280 \\
\hline \multirow{3}{*}{$\begin{array}{l}\text { Likes the } \\
\text { colour }\end{array}$} & Pearson & $.395\left(^{* *}\right)$ & $.368\left({ }^{* *}\right)$ & $.251(* *)$ & $.211(* *)$ & $.482(* *)$ & 1 & $.400\left({ }^{* *}\right)$ & $.338(* *)$ & $.271\left({ }^{* *}\right)$ & $.329\left({ }^{* *}\right)$ & $.302\left({ }^{* *}\right)$ & $.317(* *)$ \\
\hline & Correlation & & & & & & & & & & & & \\
\hline & & $\begin{array}{r}.000 \\
284\end{array}$ & $\begin{array}{r}.000 \\
285\end{array}$ & $\begin{array}{r}.000 \\
285\end{array}$ & $\begin{array}{r}.000 \\
285\end{array}$ & $\begin{array}{r}.000 \\
280\end{array}$ & $285^{\circ}$ & $\begin{array}{r}.000 \\
285\end{array}$ & $\begin{array}{r}.000 \\
285\end{array}$ & $\begin{array}{r}.000 \\
283\end{array}$ & $\begin{array}{r}.000 \\
284\end{array}$ & $\begin{array}{r}.000 \\
285\end{array}$ & $\begin{array}{r}.000 \\
283\end{array}$ \\
\hline \multirow{3}{*}{$\begin{array}{l}\text { Improve life } \\
\text { at work }\end{array}$} & Pearson & $.506\left({ }^{* *}\right)$ & $.542\left({ }^{* *}\right)$ & $.337\left({ }^{* *}\right)$ & $.285\left({ }^{* *}\right)$ & $.478\left({ }^{* *}\right)$ & $.400\left({ }^{* *}\right)$ & 1 & $.628(* *)$ & $.457\left({ }^{* *}\right)$ & $.491\left({ }^{* *}\right)$ & $.410\left({ }^{* *}\right)$ & $.459\left({ }^{* *}\right)$ \\
\hline & $\begin{array}{l}\text { Correlation } \\
\text { Sig. (2-tailed) }\end{array}$ & .000 & .000 & .000 & .000 & .000 & .000 & & .000 & .000 & .000 & .000 & .000 \\
\hline & $\mathrm{N}$ & 285 & 286 & 286 & 286 & 281 & 285 & 286 & 286 & 284 & 285 & 286 & 284 \\
\hline \multirow{3}{*}{$\begin{array}{l}\text { Feel better } \\
\text { when you work }\end{array}$} & Pearson & $.469\left(^{* *}\right)$ & $.481\left({ }^{* *}\right)$ & $.301\left({ }^{* *}\right)$ & $.250\left({ }^{* *}\right)$ & $.480\left(^{* *}\right)$ & $.338(* *)$ & $.628\left(^{* *}\right)$ & 1 & $.519(* *)$ & $.412\left({ }^{* *}\right)$ & $\left..409{ }^{* *}\right)$ & $.374(* *)$ \\
\hline & $\begin{array}{l}\text { Correlation } \\
\text { Sig. (2-tailed) }\end{array}$ & & & & & 000 & 000 & 0 & & 0 & & & 000 \\
\hline & $\begin{array}{l}\mathrm{Sig} \cdot(L \text {-tailed) } \\
\mathrm{N}\end{array}$ & 285 & 286 & 286 & 286 & 281 & $\begin{array}{r}.000 \\
285\end{array}$ & .000 & 286 & $\begin{array}{l}.000 \\
284\end{array}$ & .000 & 286 & .000 \\
\hline \multirow{4}{*}{$\begin{array}{l}\text { Produce more } \\
\text { on the job }\end{array}$} & Pearson & $.341\left(^{* *}\right)$ & $.268\left({ }^{* *}\right)$ & $.178\left({ }^{* *}\right)$ & $.236\left(^{* *}\right)$ & $.409\left(^{* *}\right)$ & $.271(* *)$ & $.457\left({ }^{* *}\right)$ & $.519\left({ }^{* *}\right)$ & 1 & $.534(* *)$ & $.560(* *)$ & $.308(* *)$ \\
\hline & Correlation & & & & & & & & & & & & \\
\hline & Sig. (2-tailed) & .000 & .000 & .003 & .000 & .000 & .000 & .000 & .000 & & .000 & .000 & .000 \\
\hline & $\mathrm{N}$ & 283 & 284 & 284 & 284 & 279 & 283 & 284 & 284 & 284 & 283 & 284 & 282 \\
\hline \multirow[t]{3}{*}{ Work safer } & Pearson & $.428\left(^{* *}\right)$ & $.370\left({ }^{* *}\right)$ & $.366\left({ }^{* *}\right)$ & $.409(* *)$ & $.440\left(^{* *}\right)$ & $.329(* *)$ & $.491\left({ }^{* *}\right)$ & $.412(* *)$ & $.534\left({ }^{* *}\right)$ & 1 & $.601\left({ }^{* *}\right)$ & $.283(* *)$ \\
\hline & $\begin{array}{l}\text { Correlation } \\
\text { Sig. (2-tailed) }\end{array}$ & & & & & & & & & & & & \\
\hline & $\mathrm{N}$ & 284 & 285 & 285 & 285 & 280 & 284 & 285 & 285 & 283 & 285 & 285 & 283 \\
\hline \multirow{3}{*}{$\begin{array}{l}\text { Work better } \\
\text { with less faults }\end{array}$} & Pearson & $.339(* *)$ & $.225(* *)$ & $.286\left({ }^{* *}\right)$ & $.314\left({ }^{* *}\right)$ & $.417(* *)$ & $.302(* *)$ & $.410(* *)$ & $.409(* *)$ & $.560(* *)$ & $.601(* *)$ & 1 & $.339(* *)$ \\
\hline & Correlation & & & & & & & & & & & & 000 \\
\hline & $\begin{array}{l}\text { Sig. (2-tailed) } \\
\mathrm{N}\end{array}$ & $\begin{array}{r}.000 \\
285\end{array}$ & $\begin{array}{r}.000 \\
286\end{array}$ & $\begin{array}{r}.000 \\
286\end{array}$ & $\begin{array}{l}.000 \\
286\end{array}$ & $\begin{array}{r}.000 \\
281\end{array}$ & $\begin{array}{r}.000 \\
285\end{array}$ & $\begin{array}{r}.000 \\
286\end{array}$ & $\begin{array}{r}.000 \\
286\end{array}$ & $\begin{array}{r}.000 \\
284\end{array}$ & $\begin{array}{r}.000 \\
285\end{array}$ & 286 & $\begin{array}{r}.000 \\
284\end{array}$ \\
\hline \multirow{4}{*}{$\begin{array}{l}\text { Enjoy work } \\
\text { more }\end{array}$} & Pearson & $.333\left({ }^{* *}\right)$ & $.317(* *)$ & $.247\left(^{* *}\right)$ & $.216\left({ }^{* *}\right)$ & $.290(* *)$ & $.317\left({ }^{* *}\right)$ & $.459(* *)$ & $.374(* *)$ & $.308(* *)$ & $.283\left({ }^{* *}\right)$ & $.339(* *)$ & 1 \\
\hline & Correlation & & & & & & & & & & & & \\
\hline & Sig. (2-tailed) & .000 & .000 & .000 & .000 & .000 & .000 & .000 & .000 & .000 & .000 & .000 & \\
\hline & $\mathrm{N}$ & 283 & 284 & 284 & 284 & 280 & 283 & 284 & 284 & 282 & 283 & 284 & 284 \\
\hline
\end{tabular}

** Correlation is significant at the 0.01 level (2-tailed).

understood the purpose (protects hearing) of the CHPD and the regression analysis also indicated three CHPD quality dimensions, namely comfort, protection and appearance (physical looks). With conventional HPDs workers tend to frequently adjust the HPD for comfort that cause leakages (a weak seal) which compromise protection. Conventional HPDs are also not durable with aesthetic features and is replaced on a regular basis. Mines (and the general public) invest much more in quality eye wear, and the observation is that hearing deserve the same treatment.

The highest correlation between items in Table 5 , is $r=0.680$ is for comfort (being better than previous one). Besides the items identified by the regression analysis, this again shows how important comfort is as determinant whether mineworkers consider the CHPD better than the previous one or not. Other high correlations as indicated in table 5 are $\mathrm{r}=0.506$ for "improve life at work" and $\mathrm{r}=0.469$ for "feel better when you work". The CHPD does not only improve working circumstances but "life at work" and "when you work" which indicates a great part of the mine workers time at work. These work life dimensions also correlate highly with other dimensions of the CHPD such as the comfort offered by the CHPD ( $r=0.542)$, communication ability, protection and the color offered by the CHPD. There is a 0.654 correlation between "improved communication on the job" and 
"hear other sounds related to the job better". Although these two CHPD quality dimensions were not rated "very good" it was at least rated "good". There is a positive correlation between "other sounds" and "communication sounds" as expected (see third factor in table 1). "Overprotection" due to high NRR levels of conventional HPDs compromises this communication ability, which is another dimension of comfort.

The CHPD (and its quality features) has a positive effect on the quality of work life. Noise control "when they work" can determine "life at work". There is a 0.628 correlation between "improve life at work" and "feel better when you work". The immediate effect of effective hearing protection (feel better when you work) has a significant effect on "life at work" since life at work is associated with continuous noise. There is a 0.519 correlation between "produce more on the job" and "feel better when you work". "Produce more" received the lowest rating (2.15) although still good. There is also a positive relationship between productivity and improve life at work $(\mathrm{r}=0.457)$. There is a 0.534 correlation between "produce more on the job" and "work safer". This is interesting, because "produce more" may usually be associated with speed and possible unsafe behavior that may lead to other injuries. This correlation actually indicates that workers work safer (due to the improved HPD that enables workers to maintain communication ability/other sounds) which relates to higher productivity. It may also be concluded that if "effective conventional hearing protection" (purely measured against attenuation ability) without features that provide communication ability, lead to overprotection, which may cause unsafe behavior and low productivity. The positive correlation $\mathrm{r}=0.409$ confirm this relationship between "hear other sounds" and "work safer".

Finally, it can be concluded that the quality (in terms of durable custom-made HPDs) pays off. Besides the direct cost saving (CHPDs is a once-off investment and conventional plugs must be replaced daily), there are also several indications of indirect cost benefits such as a 0.560 correlation between "produce more on the job" and "work better with less faults". "Produce more" could be associated with speed and possible unsafe behavior or defects. The way how the worker is protected (make them "work safer") has a positive effect on quality ("less faults"). There is a 0.601 correlation between "work safer" and "work better with less faults". It is clear that this earplug is perceived to be "more than meets the ear" and has advantages beyond hearing protection. For the workers it improves general safety, quality, performance and quality of work-life (QWL). There is a 0.459 correlation between "enjoy work more" and "improve life at work".

\section{Recommendations}

It is recommended that this survey serve as a foundation for further investigation and hypothesis testing.

It is therefore recommended that the other mine groups such as Anglo Gold should also consider testing and introducing unconventional HPDs, such as quality custom-made HPDs with filtering mechanisms. This concept offer customised comfort and comfort in terms of communication ability while being protected against noise (and several other unique quality dimensions as discussed). CHPDs also has several values beyond hearing protection that relates to safety because it promotes general safe behaviour due to effective noise control (for this reason it is also referred to as a "PHD" or "Protection Hearing Device"). A CHPD implementation strategy is thus viable for reasons such as high ownership, cost-effectiveness (a medium term once-off investment per worker), safety (not hearing only) and productivity.

\section{REFERENCES}

Bennet, C.S. 1999. Use and non-use of custom-molded and conventional hearing protectors among workers occupationally exposed to hazardous noise. Spectrum supplement 1, 2397, 2-7.

Berger, E.H. 1996. Hearing protector performance: how they work and what goes wrong in the real world. Cabot Safety Corporation, 3-4.

Berger, E.H. and Royster, L.H. 1996. In search of meaningful measures of hearing protector effectiveness. Paper delivered at the 21st Annual Conference of the National Hearing Conservation Association, San Francisco, Spectrum, $13,29$.

Cureton, Edward E. \& Stanley A. Mulaik (1975). The weighted varimax rotation and the promax rotation. Psychometrika, 40,2

Flippo, E.B. 1980. Personnel Management. (5 ${ }^{\text {th }}$ ed.) McGraw-Hill International Book Company.

Kahan, E and Ross, E. 1994. Knowledge and attitudes of a group of South African Mine workers towards NIHL and the use of HPDs. Die Suid-Afrikaanse Tydskrif vir Kommunikasieafwykings, 41.

Kerlinger, F. N. (1986). Foundations of behavioral research (3 ${ }^{\text {rd }}$ ed.) New York: Holt, Rinehart and Winston.

Kock, JFW. 2002. Industrial audiologist. Personal interview. Pretoria.

Kuhar, MS. 1995. Lost in the noise. Occupational Hazards, 57, 65. May 1995.

Rink, TL. 1996. Hearing protection works. Occupational Health and Safety, 65, October 1996, 58-64.

SAS for Windows (release 8,02) c1999-2001. SAS Institute Inc., Cary, NC,USA

Schophaus, N. 2001. Personal interview. Rustenburg.

Steenkamp RJ, 1999. Quality hearing conservation: high priority for risk managers in South Africa. Management Dynamics: contemporary research. Journal of the South Africa Institute for Management Scientists. 8 (4), 77-100.

Stevens, James,( 1992). Applied Statistics for the Social Sciences (2nd edition) Lawrence Erlbaum Associates, Publishers. Hillsdale, New Jersey. 